\title{
SEKSUALITAS DALAM PERNIKAHAN MENURUT 1 KORINTUS 7:1-5
}

\author{
Manase Gulo
}

manasegulo@sttab.ac.id

\begin{abstract}
Sexuality is God's plan for Christian marriage. But not a few deviations occur in the marriage of believers, irregularities occur because of misunderstanding the meaning of sexuality in marriage, namely in terms of assessment and application. This deviation can be found in the Corinthian church which is a very serious problem. Therefore it is very important to examine the principles of sexuality in marriage, one of the Apostle Paul's answers to the problem is in Chapter 1 Corinthians 7: 1-5, therefore to make an important contribution to understanding sexuality in marriage for believers, it is necessary to make review of exegetical studies.
\end{abstract}

Keywords: Sexuality, Marriage.

\begin{abstract}
Abstraksi: $\quad$ Seksualitas merupakan rancangan Tuhan bagi pernikahan Kristen. Namun tidak sedikit penyimpangan terjadi dalam pernikahan orang percaya, penyimpangan terjadi karena salah memahami arti seksualitas dalam pernikahan, yaitu dalam hal penilaian dan penerapannya. Penyimpangan ini bisa ditemukan dalam jemaat Korintus yang merupakan persoalan yang sangat serius. Oleh karena itu sangat penting untuk meneliti prinsip seksualitas dalam pernikahan, salah satu jawaban Rasul Paulus terhadap persoalan itu terdapat dalam Surat 1 Korintus 7:1-5, oleh karena itu untuk mendapatkan kontribusi penting pemahaman seksualitas dalam pernikahan bagi orang percaya, maka perlu untuk melakukan tinjauan studi eksegestis.
\end{abstract}

Kata Kunci: Seksualitas, Pernikahan.

\section{LATAR BELAKANG PERIKOP}

Latar belakang ungkapan Paulus dalam 1 Korintus 7 :1-5, sangat berkaitan dengan pasal 6:12-20 mengenai percabulan. Tampaknya sebagian orang Kristen mempunyai pandangan yang keliru mengenai hubungan seksual; sebagian orang membiarkan hubungan seks dengan seorang pelacur namun meremehkan hubungan perkawinan yang normal (Pfitzner, 2010:107). Kekeliruan ini sebagian orang Korintus menyalahgunanakan kebebasan orang Kristen dan kesalahan memaknai arti tubuh. Akibat dari kesalahpengertian ini, anggota jemaat Korintus melakukan praktek percabulan dan tindakan-tindakan yang tidak memuliakan Allah. Pembahasan ini telah dijelaskan dalam bab 2. 
Latar belakang yang lain adalah karena situasi di Korintus pada saat itu adanya percabulan, maka kelompok asketisme mengajarkan untuk mendapat kerohanian yang baik maka hubungan seksual termasuk hubungan seks suami istri harus ditiadakan, orang yang betul-betul mengasihi Tuhan dan mau hidup bagi Tuhan sepenuhnya harus meninggalkan pernikahan dan masuk ke dalam kehidupan membujang, dan ia dianggap sebagai orang yang lebih kudus (Kristanto, 2009:96). Tetapi disisi lain kelompok asketisme dalam konteks ini pergi ketempat pelacuran. Inti yang mau ditekankan kelompok asketisme adalah hubungan seksual adalah sesuatu yang kurang baik. Hal ini Paulus tidak setuju dengan sikap akstisme ini. Paulus menyatakan sikapnya dari ayat 2 sampai ayat 5 tentang kewajiban suami istri dalam penikahan mengenai hubungan seksual.

Kelompok asketisme ini dipengaruhi oleh filsafat Yunani diantaranya: Sinic dan Stoa, demikian juga dapat ditemukan dalam pandangan Plato. Yang lebih mementingkan jiwa dan mengabaikan tubuh yang akan dibinasakan Allah (Pandangan Sinic dan Stoa, serta Plato, dapat dilihat di bab 2). Jiwa yang penting, karena itu tidak peduli apa yang lakukan dengan tubuh. akibatnya bisa memiliki hubungan seksual dengan siapapun. Dua gagasan yang salah tentang pernikahan non-Kristen dan beberapa orang Kristen yang diadakan pada waktu itu adalah: "Pertama, 'karena jiwa (bukan tubuh) yang penting, tidak peduli apa yang kita lakukan dengan tubuh, bisa menikah atau memiliki hubungan seksual dengan siapa pun yang dipilih. "Paulus disebut ide ini dalam pasal 5 dan 6, Kedua, bahwa, "karena jiwa yang penting, harus menghindari pernikahan dan semua kesenangan tubuh sama sekali”. (Hargreaves, 1978:77).

Orang-orang Kristen di Korintus yang hidup di antara orang-orang yang memegang ide-ide seperti ini, dan karena itu tidak mengherankan bahwa beberapa dari orang-orang Kristen mulai berpikir pikiran yang sama. Ketika ini terjadi, beberapa anggota jemaat Paulus menulis surat kepada Paulus dan meminta pendapatnya (Hargreaves, 1978:77). Jawaban serta reaksi Paulus terhadap kondisi dan pertanyaan orang-orang Korintus mengenai hubungan seks dalam pernikahan, Paulus menjelaskan dalam 1 Korintus 7:1-9. Apa maksud dan tujuannya penulis akan jelaskan dalam bab selanjutnya. 


\section{VARIASI TEKS}

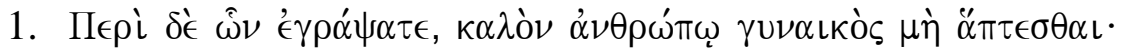

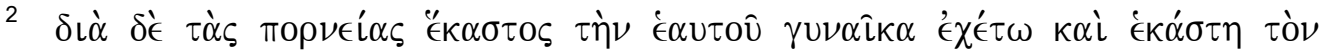

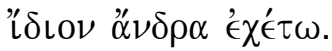

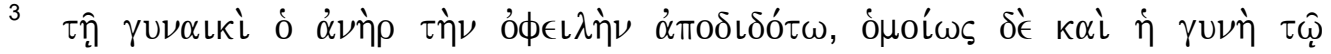
$\dot{\alpha} \nu \delta \rho \dot{l}$.

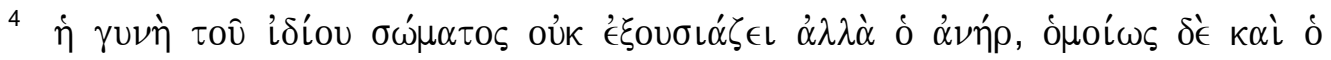

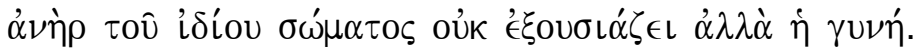

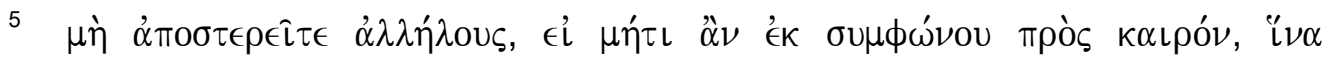

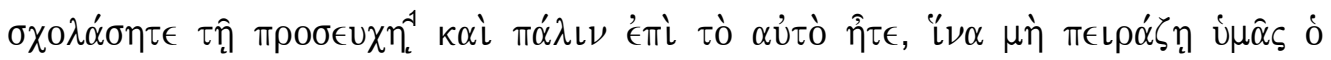

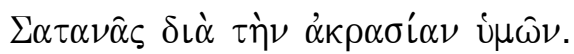

\section{STRUKTUR TEKS}

Pada bagian ini, penulis akan membuat struktur teks berdasarkan 1 Korintus 7:1-9 sebagai berikut:

\section{Ayat 1}

A. Dan mengenai surat yang kalian tuliskan (1a)

B. Baik bagi seseorang tidak menyentuh perempuan (ay.1b)

\section{Ayat 2-7}
A. Tetapi karena percabulan (2a)
B. Haruslah laki-laki mempunyai istri demikian sebaliknya (2b)
C. Haruslah Suami memenuhi Kewajiban seksual Istri demikian sebaliknya (ay. 3)

1 Beberapa naskah tua yang menggunakan kata th/| proseuch (untuk berdoa) diantaranya: naskah Sinaitikus (abad ke-4), naskah Alexandrinus (abad ke-5), naskah Vatikanus (abad ke-4), naskah Ephraemi Rescriptus (abad ke-5), naskah Claromontanus (abad ke-5), naskah Cambridge (abad ke-9), naskah Boernerianus (abad ke-9), naskah Leningrad (abad ke-6), naskah Athos (abad ke8/9). Sedangkan sebagian naskah seperti Naskah Moskow (abad ke-9), naskah Regius, naskah Paris (abad ke-8,9); miniskul (0150, 256, 365, 424 dll); bapakbapak Gereja diantaranya: Origen dan Chrysostom); Versi Byzantium, Syria, Slavia menambahkan kata th/| proseuch menjadi th/| vnhstei.a kai. th/| proseuch (untuk berpuasa dan untuk berdoa). Penambahan teks ini untuk mempertegas alasan menghilangkan hak istri supaya dapat berpuasa dan berdoa. Dan mungkin sesuai tradisi Yahudi. Penulis tetap setuju hanya menggunakan kata "berdoa" tanpa ditambakan kata "berpuasa. Sebab kata berdoa sudah pasti dipahami alasan menghilangkan hak pasangannya. 
D. Istri tidak berkuasa atas tubuhnya tetapi suami demikian sebaliknya (ay.4)

E. Janganlah kalian menjauhi satu sama lain (ay.5a)

F. Kecuali untuk persetujuan bersama dan untuk sementara waktu (ay. 5b)

G. Supaya kalian mendapat kesempatan berdoa (ay. 5c)

H. Setelah itu haruslah kembali bersama (ay. 5d)

Struktur teks ini dibuat, berdasarkan pembagian ayat dalam 1 korintus 7:19. Ayat 1 perintah kepada seseorang untuk tidak menyentuh perempuan. Ayat 2-5 Paulus memberikan perintah kepada suami istri agar memenuhi kewajiban seksual pasangan satu sama lain.

\section{EKSEGESE \\ $\underline{\text { Ayat } 1}$}

\section{Mengenai Yang Kalian Tuliskan}

Paulus dalam tulisannya pada ayat 1 menjelaskan: "dan mengenai hal-hal yang kamu tuliskan: baik bagi seseorang tidak menyentuh wanita". Kata sambung “dan” menunjukkan pernyataan Paulus dalam pasal 7 mempunyai kaitannya dengan pasal 6:12-20. Dan juga menunjukkan bahwa ada masalah di jemaat Korintus sehingga orang-orang Korintus menuliskan surat kepada Paulus.

Menurut Hodge surat ini muncul untuk menunjukan bahwa ada keragaman pendapat tentang masalah pernikahan antara orang Kristen di Korintus, mungkin sebagian berasal dari Yahudi dimana pernikahan itu wajib, sementara yang lain tidak menginginkan pernikahan (1956:108). Watson menolak argumen Hodge, karena surat ini bukan disebabkan oleh pengaruh Yahudi karena pernikahan dianggap wajib bagi laki-laki Yahudi. Surat ini lebih merupakan sebuah ekspresi dari asketisme yang disebabkan oleh eskatologi berlebihan (Watson, 1992:64). Dengan demikian Watson sependapat dengan Hargreaves, dimana kalimat ini muncul karena orang-orang Korintus meminta nasehat kepada Paulus (Watson, 1992:64). Sedangkan menurut Garland, bagian ini tidak bisa memastikan apakah orang-orang Korintus mengajukan pertanyaan atau membuat pernyataan mengenai apakah pernikahan diinginkan, apakah hubungan seksual dalam pernikahan sesuai dengan kehidupan baru atau pengalihan perhatian (2003:246). Untuk memastikannya tergantung pada teks dan bagaimana memahami budaya Korintus, namun satu hal yang jelas adalah Paulus bereaksi terhadap situasi di Korintus 
(Garland, 2003:246). Meskipun Garland tidak bisa memastikan, apakah surat Korintus, bersifat pertanyaan atau pernyataan, tetapi dari tulisan Garland, lebih cenderung bahwa surat Korintus yang ditujukan kepada Paulus dalam bagian ini adalah pertanyaan

Pemahaman ini berasal dari pengaruh kaum Eseni di Qumran yaitu kesalahpahaman mengenai kedatangan zaman baru di dalam Kristus sehingga pernikahan disingkirkan (Rosner, 2010:267), mungkin juga karena memandang tubuh rendah, yang marak dalam pemikiran Yunani dan Romawi, seperti dalam tulisan Hargreaves:

Pertama, 'karena jiwa yang penting bukan tubuh, tidak peduli apa yang dilakukan dengan tubuh. Bisa menikah atau memiliki hubungan seksual dengan siapa pun yang dipilih. "Paulus telah sebut ide ini dalam pasal 5 dan 6. Kedua, "karena jiwa yang penting, harus menghindari pernikahan dan semua kesenangan tubuh sama sekali (Hargreaves, 1978:77).

Kemungkinan hal ini berdampak kepada orang Korintus, tidak hanya berkaitan dengan penolakan kebangkitan tubuh dan pergi ketempat pelacur (6:1220) tetapi juga kearah asketis. Sebab dalam filsafat Stoa dan Sinic selibat memiliki keuntungan untuk mengejar kesalehan.

Di atas telah dijelaskan bahwa surat orang Korintus ditujukan kepada Paulus, sifatnya pertanyaan. Yang menjadi pertanyaan adalah apakah ungkapan baik bagi seseorang kalau tidak menyentuh perempuan merupakan kutipan atau pernyataan Paulus sendiri?. Umunya penafsir menyatakan bahwa "baik bagi seseorang tidak menyentuh wanita" (ay.1b) adalah kutipan Paulus . Alasan Fee seperti dalam 6:1-13; 8:1,4. (1987:276). Alasan lain adalah penggunaan frase peri de (mengenai hal), ungkapan ini muncul lima kali di surat yang lain 7:25; 8:1; 12:1; 16:1; 16:12 (Garland, 2003:249; Hitler, 1974:490-491; Drewes, 2006:69; Kistemaker, 2007:210; Napel, 2012:140; Schäfer \& Ross, 2012:154). Bahkan Thiselton menyatakan ayat $1 \mathrm{~b}$ paling baik dipahami sebagai kutipan dari orang Korintus karena Paulus tidak sepenuhnya setuju (2000:501).

\section{Baik Bagi Seseorang Tidak Menyentuh Perempuan}

Terjemahan yang lain dari frase kalo.n avnqrw,pw| gunaiko.j mh. a[ptesqai ada yang menerjemahkan baik bagi seseorang tidak menyentuh istrinya (Powers, 2011:87). Istilah "istri” adalah terjemahan dari kata gunaiko.j. Karna kata 
gunaiko.j dapat diterjemahkan perempuan atau istri. Hal yang menguatkan bahwa kata gunaiko.j lebih tepat diterjemahkan "istri" karna di ayat 2 muncul kata gunaika diterjemahkan istri. demikian juga ayat 3 kata yang dipakai gunaiki ayat 4 digunakan kata gunh semua kata ini diterjemahkan istri. Alasan lain yang menguatkan adalah Paulus berbicara dalam konteks hubungan seksual suami istri.

Kedua arti kata gunaiko.j yaitu "perempuan" atau "istri" keduanya mengacu kepada hubungan seksual suami istri dalam pernikahan. Karena dalam latar belakang perikop di atas telah dijelaskan surat yang dituliskan sebagian orang Korintus menanyakan masalah-masalah sekitar hubungan seks dalam pernikahan. Jika demikian apakah maksud dari frase baik bagi seseorang tidak menyentuh perempuan.

Menurut Hillyer menyentuh wanita atau menjamah wanita, suatu ungkapan yang halus untuk mengungkapkan hubungan seksual (bdg. Kej. 2:6; 1974:490-491). Garland, sependapat kata kerja menjamah wanita yang dimaskud eufemisme untuk melakukan hubungan seksual (Garland, 2003:254). Baik jemaat Korintus maupun Paulus memaksudkan ungkapan ini secara hurufiah yaitu baik bagi seseorang tidak berhubungan seksual. Ungkapan "menyentuh wanita" dalam literatur kuno muncul sebanyak 9 kali dengan arti "bersetubuh dengan wanita (Fee, 1987:275). Kesimpulan ini dapat dibandikan dalam Kejadian 20:6; Amsal 6:29. Dalam hal ini Amsal 6:29 lebih jelas karena "menghampiri wanita" disejajarkan dengan "menyentuh wanita". Makna seperti ini juga didukung oleh konteks 1 Korintus 7 . Isu yang dibahas bukan hanya sekadar tentang pernikahan, tetapi juga hubungan seksual (7:3-5).

Tidak berhubungan seksual keadaan ini baik, tetapi karena bahaya percabulan Paulus katakan dalam ayat 2 haruslah laki-laki hanya berhubungan seksual dengan istrinya sendiri demikian perempuan hanya berhubungan seksual dengan suami sendiri. Paulus menyadari bahwa ada orang yang tidak memiliki karunia selibat, Pernyataan ini telah dijelaskan sebelumnya di point pertama yaitu muncul karna sebagian jemaat Korintus telah dipengaruhi oleh kelompok asketisme melarang melakukan hubungan seks, tetapi disisi lain kelompok ini pergi ke tempat pelacuran. 
Menurut Schafer \& Ross frase "baik bagi seseorang tidak berhubungan seksual adalah bukan penolakan umum terhadap hubungan seksual apapu pun, tetapi hanya sebuah penolakan praktik seks laki-laki tertentu, misalnya kunjungan pada pekerja seks komersial. (2012:158). Karena berhubungan seksual dengan wanita yang lain itu adalah jahat, dan berdosa (Barrett, 1993:154). Maksud lain yang juga karena pada saat itu percabulan marajalela, sebagian jemaat Korintus berpikir sekarang setelah menjadi orang Kristen tidak perlu melakukan hubungan seksual, termasuk dalam hubungan seksual suami istri (Hargreaves, 1978:78). Paulus menjawab pernyataan ini dengan mengatakan suami istri harus saling memenuhi kewajiban seksual satu dengan yang lain (1 Kor. 7:3).

Pendapat lain adalah misalnya Winter yang dikutip Schafer dan Ross, menyatakan: pantangan hubungan seksual adalah metode perencanaan keluarga. Karena bencana kelaparan, pada waktu itu di Korintus dan barangkali dipahami sudah dekatnya akhir dunia, orang tidak mau menambahkan anak pada keluarganya (2012:156). Karena itu baik kalau tidak berhubungan seksual. Pandangan ini tidak mungkin karena konteks bagian ini bukan tentang perencanaan keluarga tetapi konteks ini adalah percabulan . Menurut Ridderboss ayat $1 \mathrm{~b}$ "baik bagi seseorang tidak berhubungan seksual" berhubungan dengan waktu darurat sekarang (ay.26) waktu telah singkat (ay. 29) dunia akan berlalu (ay. 31) intinya adalah untuk menghadapi kerajaan Allah (2010:326). Pandangan ini sesuai dengan konteks keseluruhan pasal 7.

"Baik" dalam ayat 1b juga merujuk kepada moral atau spiritual (Fee, 1987:275), Moral bukan berhubungan dengan "pengekangan perkawinan atau keperawanan" (Kittel, 1978:536) tetapi menjauhkan diri dari hubungan seks yang bukan pasangannya. Spiritual lebih berhubungan dengan efektivitas pelayan. Bagi Paulus, tidak menikah memang baik, tetapi kebaikan itu berkaitan dengan efektivitas pelayanan.

Bagi Paulus sikap seperti itu terpuji apabila ia memiliki karunia itu dan demi pelayanan. Akan tetapi tidak memiliki karunia itu, juga, bukan berarti tidak baik. Menurut Ridderbos, Jika tekanan untuk menikah terlalu besar, maka biarlah ia menikah ia tidak berdosa. Tetapi ia yang benar-benar yakin dalam hatinya dan yang tidak dipaksa untuk tidak menikah yang dapat menguasai kemauannya dan 
memutuskan untuk tidak menikah, ia berbuat baik (2008:327). "Selibat baik karena hal itu memungkinkan seseorang melayani Tuhan dan orang lain dengan cara yang khusus tetapi Paulus tidak mengatakan bahwa seseorang akan menjadi lebih baik atau lebih diterima di mata Allah karena ia bertarak" (Priftzner, 2010:108). Artinya Paulus mau menekankan baik dalam ayat ini, lebih kefektifan pelayanan sebab orang yang tidak menikah memusatkan perhatiannya pada perkara Tuhan (ay. 32b); supaya melakukan yang benar dan baik dan melayani Tuhan tanpa gangguan dan supaya tubuh dan jiwanya kudus (ay. 34)

\section{$\underline{\text { Ayat } 2}$}

Dalam ayat 2 ini, Paulus memberikan perintah "tetapi mengingat bahaya percabulan, haruslah/ hendaklah setiap laki-laki mempunyai istri sendiri dan setiap perempuan mempunyai suami sendiri. Untuk memahami bagian ini penulis menyelidiki beberapa kata dalam teks Yunani antara lain:

Ketika Paulus mengatakan karena bahaya percabulan, Paulus mendorong pembacanya menghindari percabulan, karena inilah kehendak Allah: “pengudusanmu yaitu supaya kamu menjauhi percabulan” (1 Tes. 4:3). Paulus menyadari percabulan telah mempengaruhi kehidupan Korintus karena ungkapan karena banyak percabulan menggambarkan bahwa sering adanya hubungan dengan pelacur (Kistemaker, 2007:211).

Percabulan yang sudah dibahas di 5:1-13 dan 6:12-20 cukup sebagai bukti betapa berbahayanya situasi di Korintus. Bentuk jamak "percabulan" (ta.j pornei,aj) yang dipakai di 7:2a menyiratkan berbagai kemungkinan yang berpotensi menjatuhkan jemaat Korintus (Handoko, 2009:3). Atau dapat dipastikan mengacu kepada kasus-kasus prostitusi, karena dalam ayat 5 "ada frase kurang mengontrol diri, ini berbicara kepada orang yang sudah menikah yaitu beberapa suami telah merampas hak dari hubungan seksual dan pergi ke pelacuran (Fee, 1987:278).

\section{Harus Mempunyai Suami dan Istri sendiri}

Kata evce,tw (mempunyai) dalam ayat 2 muncul dua kali. Dua-duanya berbentuk present imperative aktif. Penggunaan pertama dalam kalimat teks Yunani e[kastoj th.n e'autou/ gunai/ka evce,tw( umumnya penerjemah seperti LAI, NIV, KJV menerjemahkan “setiap laki-laki mempunyai istri sendiri”. Kedua, 
e`ka,sth to.n i;dion a;ndra evce,tw umumnya diterjemahkan setiap perempuan mempunyai suami sendiri. Karena kasusnya imperative maka penulis menerjemahkan setiap laki-laki, haruslah mempunyai istri sendiri dan setiap perempuan haruslah mempunyai suami sendiri. Bentuk imperative menunjukkan bahwa ini adalah perintah yang ditujukan Paulus kepada jemaat Korintus baik kepada laki-laki maupun perempuan. Yang menjadi pertanyaan dalam kalimat ini adalah apakah perintah ini ditujukan kepada orang yang belum menikah atau kepada orang yang sudah menikah?

Sesuai dengan konteks bahwa ungkapan Paulus dalam ayat $2 \mathrm{~b}$ menunjuk kepada orang yang telah menikah karna Pertama, ungkapan "mempunyai istri" (gunai/ka). Ungkapan ini tidak dapat diartikan "menikah". Karena kata kerja "mempunyai" dimaksudkan sebagai eufimisme untuk melakukan hubungan seksual, dan juga digunakan dalam 7:12,13,29 yang mengacu pada status telah menikah (Garland, 2003:256; Kistemaker, 2007: 211). Istilah lain untuk mempertahankan hubungan seksual secara teratur (Ciampa \& Rosner, 2010:276). Jika Paulus memaksudkan "menikah", maka Paulus mungkin akan menggunakan ungkapan "lambanw. gunai/ka, mempunyai istri (Tobit 4:12), bukan gunai/ka evce,tw (mempunyai istri). Ia juga bisa memakai kata yang lebih jelas yang nanti akan dia pakai di bagian selanjutnya, yaitu gamh/sai terutama 7:9 "biarlah ia kawin. Berdasarkan pemunculan ungkapan e,ce,tw. $\square$ gunai/ka dalam LXX, dapat mengetahui bahwa ungkapan ini memiliki arti "berhubungan seksual bdk.Kel 2:1; U1 28:30; Yes 13:16" (Handoko, 2009:4), lihat juga Matius 6:18; 12:33; Yohanes 4:18 (Garland, 2003:256)

Dengan demikian, maksud "setiap laki-laki mempunyai mempunyai istri sendiri dan sebaliknya" yaitu Paulus memberikan nasehat "hendaklah setiap lakilaki berhubungan seks sendiri dengan istrinya, dan hendaklah setiap perempuan berhubungan seks dengan suaminya sendiri. Fee juga mengatakan "Biarlah setiap orang yang sudah menikah terus dalam hubungan dengan istrinya sendiri, dan sebaliknya" (1987:279). Jika melupakan hal ini, maka bahaya percabulan siap menghadang. Menjauhkan diri dari pasangan (bdk. 7:5) bukanlah ide yang bijaksana jika dilihat dari potensi kejatuhan yang akan terjadi. 


\section{Harus Memenuhi Kewajiban Suami Istri (Ayat 3)}

Kata kerja "memenuhi” dalam teks Yunani menggunakan kata avpodido,tw dalam bentuk kata kerja present imperative active orang ke-3 tunggal dari kata avpodidwmi artinya menyerahkan; membayar; memberikan kembali; melunasi. Present imperative aktif mengacu kepada perintah. Jadi, ovfeilh.n avpodido,tw secara harafiah diterjemahkan haruslah memenuhi kewajiban. Bentuk present tense dari kata avpodido,tw, menunjukkan perintah ini harus dilakukan terusmenerus. Artinya haruslah memenuhi kewajiban terus menerus.

Untuk mengerti maksud ungkapan "memenuhi kewajiban" dalam ayat ini, penulis akan menjelaskan apa yang dimaksud dengan "kewajiban". Dalam teks Yunani menggunakan kata ovfeilh.n bentuk kata benda feminim akusatif tunggal dari kata ovfeilh... Secara harafiah artinya "utang atau kewajiban. Istilah hutang atau kewajiban dalam ayat ini merupakan bahasa kiasan, yang mendukung istilah kiasan ini yakni manuscript Sinatikus, Alexandrinus, Vaticanus, Ephraemi Rescriptus, Cambridge, Coptic, Tertullian, Clement, Origen, Cyprian (Thiselton, 2000:503). Kewajiban yang dimaksud Paulus dalam ayat ini adalah "is the mutual obligation of spouses deriving from the order of creation" (Kittel, 1978:564). Fee mempertegas maksud kata ovfeilh.n yaitu suami dan istri berhutang kepada satu sama lain secara seksual (1987:279).

Untuk memahami maksud frase "memenuhi kewajiban" yang dimaksud Paulus dalam ayat 3 ini, menurut Fee, harus dilihat dalam terang ayat 5, dimana beberapa orang telah merampas hak hubungan seksual pasangan, meski bukan karena tugas utama (1987:279). Karena itu Paulus tidak meminta yang kuat membantu yang lemah tetapi Paulus menggunakan retorika kesetaraan yaitu untuk menghindari kemaksiatan laki-laki atas hak perempuan tentang hubungan seksual (Thiselton, 2000:504). Sehingga maksud memenuhi kewajiban baik suami maupun istri adalah suami maupun istri memenuhi kewajiban seksual satu sama lain di dalam pernikahan.

Meskipun berhubungan seks adalah kewajiban, namun seks harus tetap dipandang sesuatu yang indah. indah karena tidak boleh dipermainkan sembarangan. Indah karena ketika dilakukan pada tempatnya menjadi kunci dan sarana memberikan kebahagiaan bagi manusia (Subeno, 2008:88). 


\section{Suami Istri Tidak Berkuasa Atas Tubuhnya (Ay. 4)}

Istilah "tidak berkuasa" dalam teks Yunani menggunakan kata ouvk evxousia,zei. Kata ouvk adalah partikel negative artinya tidak. Sedangkan evxousia,zei adalah bentuk kata kerja present indikatif aktif orang ke-3 tunggal, dari kata dasar evxousia,zw aku berkuasa. Jadi, secara harafiah terjemahan ouvk evxousia,zei yaitu ia (suami-istri) tidak berkuasa atas tubuh masing-masing. Bentuk present indikatif disini menekankan bahwa nasehat Paulus kepada jemaat Korintus adalah agar tindakan yang dilakukan untuk terus menerus yaitu baik suami maupun istri saling memilki tubuh yang satu dengan yang lain. Yang dimaksud dengan tubuh di sini terutama adalah alat-alat seksual.

Konsep kepemilikan tubuh bersama di atas didasarkan pada dua pemikiran. Yang paling penting, relasi suami-istri memang menyangkut proses menjadi satu daging bdk. Kej 2:24 (Handoko, 2009:2). Dalam Kidung Agung kedekatan relasi suami-istri berkali-kali digambarkan dengan ungkapan "kekasihku kepunyaanku dan aku kepunyaan dia" (2:16; 6:3; 7:10). Jangankan dengan suami-istri sendiri, perzinahan dengan pelacur pun sudah menciptakan kesatuan yang lebih serius daripada sekadar kontak fisik. Perzinahan membuat seseorang menjadi satu tubuh dengan yang dia ajak berzinah (6:16). Dasar yang lain adalah prinsip kasih (Handoko, 2009:2). Orang yang menikah harus mulai memikirkan kepentingan atau urusan pasangannya (7:33-34). Salah satu wujud kasih adalah "tidak mencari kepentingan sendiri tetapi orang lain" (13:7). Setiap orang Kristen harus menunjukkan kasih dalam bentuk tidak mau melakukan sesuatu yang menjadi batu sandungan bagi orang lain, sekalipun ia mungkin memiliki alasan atau hak untuk melakukan hal tersebut $(8: 9,13 ; 10: 24,33)$. Kasih mengendalikan semua hubungan-hubungan Kristen. tidak mencari keuntungan sendiri (13:5), (berusaha menyenangkan hati semua orang (10:33).

\section{Ayat 5}

\section{Janganlah Menjauhi Satu Sama Lain}

Kata kerja "menjauhi" dalam teks Yunani menggunakan "avposterei/te" dalam bentuk kata kerja present imperative active dari kata dasar avpostere, $\mathrm{w}$ artinya merampas, merampok, mencuri, menolak, menghilangkan. Menjauhi juga dimaksud menahan untuk melakukan hubungan seksual secara terus menerus 
(Hillyer, 1974:491). Bentuk present imperatif dari kata mh. avposterei/te lebih bermakna "berhentilah menolak" hubungan seks dengan pasangan (Handoko, 2009:3). Karna ketika tidak mau melakukan hubungan seksual, sebenarnya sedang merugikan sesuatu, yaitu hak atau otoritas dari pasangan masing-masing. Atau membuat orang lain mengalami kerugian dengan cara-cara ilegal (Rosner \& Ciampa; 2010:281; Thiselton, 2000:506-507). Istilah Priftzner menjauhi pasangan berarti menyangkal hak-hak perkawinan pasangan, dan itu sama dengan pencuri, bahkan menjauhkan diri karena alasan yang dianggap rohani pun berarti merampas, bila itu dilakukan secara sepihak (Priftzner, 2010:109 Barret, 2003:261).). Present imperatif dari kata " mh. avposterei/te sebenarnya dimaksudkan berhenti menipu (Fee, 1987:280). Atau merampas satu sama lain (Thiselton, 2000:507). Sikap yang seperti inilah yang tidak diperbolehkan oleh Paulus terhadap pasangan suami-istri.

Ketika Paulus memberikan perintah janganlah merampas hak satu sama lain, "Paulus mengikuti ajaran dan perilaku Yesus, yang memperlakukan tubuh sebagai bagian yang sangat penting dari setiap orang" (Hargreaves, 1978:81). "Yesus tidak ingin memisahkan tubuh dari bagian spiritual, Yesus datang untuk membawa keutuhan kepada semua orang” (Hargreaves, 1978:81).

\section{Persetujuan Bersama}

Persetujuan bersama yang dimaksud Paulus dalam ayat ini bukan perintah melainkan konsesi (Fee, 1984:281). Paulus memang mengizinkah menjauhi untuk bersetubuh pada suatu waktu, tetapi Paulus sebenarnya tidak memberikan perintah untuk itu. Tindakan menjauhi pasangan dalam ayat ini sesuai dengan apa yang memang sudah terjadi dalam jemaat Korintus. Orang-orang Korintus bukan sekedar memiliki konsep yang salah, tetapi sungguh sungguh sudah mempraktikkan konsep tersebut. Paulus memberi nasehat agar berhenti melakukan kesalahan ini (Handoko, 2009:3).

Kesalahan pada saat itu karena keputusan suami hanya bersifat pemberitahuan kepada istri bukan kesepakatan (Garland, 2003:261). Tradisi seperti ini yang ditentang oleh Paulus. Menolak hubungan seksual harus persetujuan bersama, dan untuk sementara waktu (Rosner \& Ciampa, 2010:282). Sebab apabila pantangan itu permanen maka dapat mengakibatkan kehancuran 
dalam pernikahan yang akhirnya kepada percabulan. Percabulan tidak hanya bertentangan dengan istitusi perkawinan (Kej. 2:24: Mrk, 10:2-9) tetapi mengalahkan tujuan berpantang untuk mendapat kerohanian yang tinggi (Kistemaker, 2007:213). Inilah alasan Paulus memberikan perintah untuk tidak menolak berhubungan seksual dalam waktu yang lama.

\section{Sementara Waktu}

Preposisi pro.j adalah bentuk akusatif, dan kairo,n kata benda akusatif maskulin singular. Ungkapan pro.j kairo,n (sementara waktu) dapat berarti "untuk musim” (Lihat Luk. 8:13; 1 Tes. 2:17), atau sesuai waktu yang ditetapkan (Fee, 1987:281). ketika Paulus menyisipkan frase sementara waktu, berarti bukan dalam waktu yang permanen. Sebab sebagian berpikir bahwa semakin lama bertarak akan semakin baik bagi kerohanian (Handoko, 2009:3). Tentang hal ini Paulus memberi syarat yang jelas, yaitu "untuk sementara waktu". Di bagian akhir ayat 5 Paulus memakai dua kata kerja subjunctive untuk menunjukkan tujuan. Dan kedua kata kerja subunctif diawali dengan dua kata i[na. Dalam tata bahasa Yunani ketika kata kerja subjunctive diawali penghubung i[na berarti terjemahan kata tersebut menyatakan tujuan. Tujuan di sini bukan menerangkan "kecuali atas persetujuan bersama", tetapi "untuk sementara waktu".

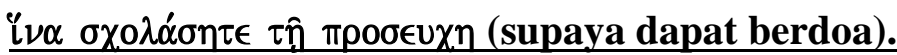

Tujuan berdoa adalah menurut Ignatius yang dikuti Garland, untuk memberikan waktu kepada Allah (Garland, 2003:1). Sedangkan Menurut Rosner \& Ciampa untuk menyampaikan serta membawa masalah pergumulan di hadapan Allah (2010:283). Dalam pandangan ini seks dalam perkawinan tidak dilihat sebagai kejahatan atau hambatan, tetapi sebagai berkat (Rosner \& Ciampa, 283). Ini menunjukkan bahwa doa sangat penting. Doa dan berpuasa salah satu bentuk penyangkalan diri. Di dalam doa menanggalkan segala keinginan dan meletakan di bawah keinginan Tuhan, dan menyerahkan diri sepenuhnya untuk dipakai Tuhan menurut kehendakNya (Kristanto, 2009:99).

Doa harian adalah ciri khas dari setiap orang Kristen yang tulus. "Tetapi dalam kehidupan pernikahan, suami dan istri pada waktu menghadapi krisis memerlukan doa khusus. Misalnya masalah keuangan, masalah spiritual, atau hidup tampaknya, melarikan diri kepada Allah dalam doa. Pada saat seperti itu, 
mungkin secara sukarela dan untuk sementara menjauhkan diri dari keintiman pernikahan" (Kistemaker, 2007:213).

Paulus mengembangkan tradisi Yahudi, namun Paulus tambahkan setiap yang mau berpantang hubungan seksual hanya mungkin terjadi setelah suami istri bersepakat. Dari sini terlihat bahwa tidak boleh mengeksploitasi waktu doa seenaknya demi menghilangkan hubungan seks. Walaupun doa merupakan sesuatu yang rohani dan penting bagi orang Kristen, namun hal ini tidak bisa meniadakan kewajiban suami-istri dalam hal seksual. Ini berarti bahwa di mata Paulus, berdoa dan melakukan hubungan seks dengan pasangan sama-sama merupakan perkara yang rohani.

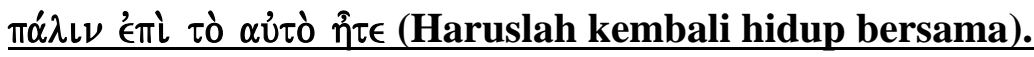

Situasi dalam kehidupan jemaat Korintus yang rawan dengan percabulan (6:15-16; 7:2a) merupakan senjata ampuh bagi iblis untuk menjatuhkan. Masalah ini semakin diperparah dengan keadaan beberapa jemaat yang memang tidak tahan bertarak (7:5, 9). Sebab penggoda akan menggunakan nafsu seskual seseorang untuk menemukan pemuasaannya dengan cara yang tidak bermoralsekurang-kurangnya itulah kekuatiran Paulus (Pfitzner, 2010:109). Paulus memberikan petunjuk kalau berpantang hanya sementara waktu supaya tidak jatuh ke dalam dosa seksual. Dorongan seksual sangat kuat, dan setan adalah musuh yang kuat (Garland, 2003:262). "Upaya selibat dapat menyebabkan menjadi korban hukum sebagai akibat yang tidak disengaja dan tidak membawa lebih dekat kepada Allah, karena membuat lebih rentan terhadap godaan setan, sebab setan diyakini merangsang orang untuk melakukan amoralitas" (Garland, 2003:262). Paulus sudah mengetahui hal ini, karena itu ia memberikan konsensi bagi yang tidak memiliki karunia untuk membujang (bdg. 7:7-8), Berpijak dari pertimbangan ini, maka tindakan jemaat yang meninggalkan hubungan seksual dengan pasangan dalam waktu yang lama merupakan tindakan yang bodoh, karena memberi kesempatan kepada iblis.

\section{Ketidaksanggupan mengendalikan diri}

Kata benda avkrasi,an adalah acusative feminism singular diterjemahakan ketidaksanggupan. LAI menerjamah karena kamu tidak tahan bertarak. Terjemahan LAI ini menjadikan kata benda avkrasi,an menjadi kata kerja yaitu 
bertarak. Penulis memilih terjemahan ketidaksanggupan diri. Frase ini merupakan alasan mengapa Paulus mengharuskan kembali suami istri hidup bersama (berhubungan seksual) setelah selesai berdoa karena ketidaksanggupan mengendalikan diri terhadap nafsu seksual. Karna menurut Garland, ketika beranggapan bahwa dapat mengendalian diri dengan kekuatan sendiri maka paling rentan untuk jatuh ke dalam dosa percabulan (Garland, 2003:263). Karena setan, yang berusaha mengeksploitasi kelemahan manusia dengan menggoda suami atau istri dalam melakukan perzinahan (Kistemaker, 2007:213), pada saat bertarak dalam waktu yang lama. Hal ini bertentangan dengan ketentuan Allah terhadap lembaga pernikahan dan tujuan selsualitas seksualitas diberikan.

Kesimpulannya adalah frase janganlah merugikan satu sama lain, maksudnya adalah jangan merampas hak pasangan untuk tidak berhubungan seksual secara sepihak meskipun itu menyangkut hal rohani, kecuali dengan persetujuan bersama untuk sementara waktu. Kesepakatan yang dimaksud Paulus adalah menekankan kesetaraan jender dalam hubungan intim. Tujuanya adalah supaya mendapat kesempatan untuk berdoa, untuk membawa segala pergumulan di hadapan Allah. Sesudah itu haruslah kalian kembali hidup bersama-sama, supaya Iblis jangan menggodai, karena ketidaksanggupan mengendalikan diri. Karena ketika hubungan seksual dijauhi secara terus menurus atau menolak secara permanen, itu akan membawa kejatuhan dalam dosa percabulan dan akhirnya keluarga menjadi berantakan, karna iblis akan menggunakan nafsu seksual untuk menjatuhkan dosa seksual.

\section{PENUTUP}

Seksualitas dalam pernikahan sangat penting karena seksualitas sarana untuk menyatakan kasih. Namun dalam seksualitas juga harus memperhatikan beberapa hal, yaitu kasih Allah menjadi dasar dalam pernikahan, sehingga seksualitas dalam pernikahan juga sebagai perwujudan dari pasangan yang telah dikasihi Allah. Jika kasih menjadi dasar pernikahan maka tiap pasangan harus mematikan keegoisannya dan harus mau berbagai dengan pasangan. Lalu dalam pernikahan seksualitas tidak akan dirasakan indah jika masih ada persoalanpersoalan dalam relasi pasangan, oleh karena itu jika ada persoalan yang serius agar pasangan menyelesaikan persolan terlebih dahhulu, jika memang berat maka 
pasangan berpisah bukan untuk bercerai tetapi saling berdoa masing-masing untuk merenungkan kasih Allah dalam hidupnya agar nanti kembali bersama untuk menunjukkan kasih. Permasalahan seksualitas dalam pernikahan harus juga diselesaikan agar tidak memberi peluang kepada iblis untuk merusak ikatan pernikahan. Seksualitas dalam pernikahan dimulai dari kasih Allah bermuara pada memuliakan Allah. 


\section{DAFTAR PUSTAKA}

Barret, C.K.. (1993). The First Epistle To The Corithians, Michigan: Baker Publishing Group.

Blomberg, Craig. (1994). NIV Application Commentary, New Testament: 1 Corinthians, Grand Rapids: Zondervan.

Calvin, John. (1993). Commentary On The Epistle Of Paul The Apostle To The Corinthians, Grand Rapids: Michigan.

Colins \& Edward G. Farrugia. (1991). Kamus Teologi, Yogyakarta: Kanisius.

Conzelmann, Hans. ( 1975). 1 Corinthians, Fortress Press, Philadelphia.

Drewes, B.F, Wilfrid Haubeck, Heinrich Von Siebenthal. (2006). Kunci Bahasa Yunani PB, Surat Roma Hingga Kita wahyu, Jakarta: BPK Gunung Mulia.

Fee, Gordon D. (1987). The First Epistle To The Corinthians, Grand Rapids: Michighan.

Garland, David E. (2003). 1 Corinthians, Michigan: Grand Rapids.

Handoko, Yakub Tri. (2009). Mimbar GKRI Exodus, 11 Januari. (2009). Mimbar GKRI Exodus, 08 Februari.

Hargreaves, John. (1987). A Guide To 1 Corinthians, London: SPCK.

Hillyer, Norman. (1974). Tafsiran Alkitab Masa Kini 3 Matius-Wahyu, Jakarta: Yayasan Komunikasi Bina Kasih.

Hodge, Charlesa. (1956). An Exposition Of The First Epistle To The Corinthians, New York: Robert Carter \& Brothers, 530 Broadway.

John D. Harvey. (1998). Listening To The Text Oral Patterning In Paul Letters, Michigan: Grand Rapids Baker Books.

Kistemaker, Simon J. (2007). N New Testament Commentary 1 Corinthians, Grand Rapids: Michigan.

Kittel, Ed. Gerhard Friedrich. (1978). Theological Dictionary Of The New Testament, Michigan: Grand Rapids.

Kristanto, Billy. (2009). Refleksi Atas Surat Korintus, Surabaya: Momentum.

Orr, William F \& Walther James Arthur. (1976). 1 Corinthians, A New Translation Introduction With A Study Of The life Of Paul, Notes, And Commentary, New York: Garden City. 
Pfitzner, V.C. (2006). Kesatuan Dalam Keberbagaian, Jakarta: BPK. Gunung Mulia.

Powers, B. Ward. (2011). Perceraian Dan Perkawinan Kembali, Jakarta: Yayasan Bina Kasih.

Rosner, Brian \& Ciampa, Roy E. (2010). The Pilar New Testament Commentary The First Letter To The Corinthians, Grand Rapids: Baker House.

Schafer, Ruth \& Freshia Aprilyn Ross. (---). Bercerai Boleh Atau Tidak?, Jakarta: LAI.

Subeno, Sutjipto. (2008). Indahnya Pernikahan Kristen, Surabaya: Momentum.

Tabor, James. (2007). Dinasti Yesus, Sejarah Tersembunyi Yesus, Keluarga Kerajaan-Nya Dan Kelahiran KeKristenan, Jakarta: Gramedia

Thiselton, Anthony C. (2000). The First Epistle To The Corinthians, Michigan: Grand Rapids.

Tong, Stephen. (2009). Keluarga Bahagia, Surabaya: Momentum.

Watson, Nigel. (1992). The First Epistle To The Corinthians, Epworth Press. 